\title{
Lactic acid bacterial bacteriocins and their bioactive properties against food- associated antibiotic-resistant bacteria
}

Emmanuel Edoghogho Imade ${ }^{1}$, Solomon Esharegoma Omonigho ${ }^{1}$, Olubukola Oluranti Babalola $2^{*}$ (D) and Ben Jesuorsemwen Enagbonma ${ }^{2}$ (1)

\begin{abstract}
Purpose: Incidence of foodborne diseases and growing resistance of pathogens to classical antibiotics is a major concern in the food industry. Consequently, there is increasing demand for safe foods with fewer chemical additives but natural products which are not harmful to the consumers. Bacteriocins, produced by lactic acid bacteria ( $L A B)$, is of interest because they are active in a nanomolar range, do not have toxic effects, and are readily available in fermented food products.
\end{abstract}

Methods: In this research, LAB were isolated from fufu, gari, kunu, nono, and ogi using De Mann, Rogosa, and Sharpe agar. Cell-free supernatants were prepared from 18-24 h LAB culture grown on MRS broth. Effect of organic acid was eliminated by adjusting the $\mathrm{pH}$ of the supernatants to 7.0 with $1 \mathrm{M} \mathrm{NaOH}$ while the effect of hydrogen peroxide was eliminated by treating with Catalase enzyme. The supernatant was then filter-sterilized using a membrane filtration unit with a $0.2-\mu \mathrm{m}$ pore size millipore filter and subjected to agar well diffusion assay against foodborne antibiotic-resistant bacteria.

Result: A total of 162 isolates were obtained from the food samples. The antimicrobial sensitivity test yielded positive results for 45 LAB isolates against Staphylococcus aureus ATCC 25923 while 52 LAB isolates inhibited Escherichia coli ATCC 25922. On confirmation of the bacteriocinogenic nature of the inhibitory substance, 4 of the LAB isolates displayed a remarkable degree of inhibition to Leuconostoc mesenteroides, Salmonella typhimurium, and Bacillus cereus. Agar well diffusion assay was also performed against antibiotic-resistant foodborne pathogens using the cell-free supernatant (CFS) obtained from Lactobacillus fermentum strain NBRC15885 (Limosilactobacillus fermentum), Lactobacillus fermentum strain CIP102980 (Limosilactobacillus fermentum), Lactobacillus plantarum strain JCM1149 (Lactiplantibacillus garii), and Lactobacillus natensis strain LP33 (Companilactobacillus nantensis). The foodborne pathogens exhibited a notable level of resistance to antibiotics, with $B$. cereus exhibiting a resistance profile of 40\%, S. aureus (50\%), K. pnuemoniae (70\%), E. coli (60\%), and S. typhi (40\%). The (CFS) was able to inhibit the growth of B. cereus, Klebsiella pneumonia, S. typhimurium, S. aureus, and E. coli.

Conclusion: Therefore, it portends that the bacteriocins produced by the LAB isolated from these food products could act as probiotics for effective inhibition of the growth of antibiotic-resistant foodborne pathogens.

Keywords: Drug-resistant microorganisms, Fermented food, Inhibitory activity, Probiotics

\footnotetext{
* Correspondence: olubukola.babalola@nwu.ac.za

${ }^{2}$ Food Security and Safety Niche Area, Faculty of Natural and Agricultural Sciences, North-West University, Private Bag X2046, Mmabatho 2735, South Africa

Full list of author information is available at the end of the article
}

(c) The Author(s). 2021 Open Access This article is licensed under a Creative Commons Attribution 4.0 International License, which permits use, sharing, adaptation, distribution and reproduction in any medium or format, as long as you give appropriate credit to the original author(s) and the source, provide a link to the Creative Commons licence, and indicate if changes were made. The images or other third party material in this article are included in the article's Creative Commons licence, unless indicated otherwise in a credit line to the material. If material is not included in the article's Creative Commons licence and your intended use is not permitted by statutory regulation or exceeds the permitted use, you will need to obtain permission directly from the copyright holder. To view a copy of this licence, visit http://creativecommons.org/licenses/by/4.0/ 


\section{Introduction}

One of the concerns in the food industry is the contamination of food by pathogens, which are a frequent cause of foodborne diseases. Recurrent outbreaks of diarrhea and other foodborne illnesses combined with the natural resistance of the causative agents is a huge risk to global health, food security, and development (Caniça et al. 2019; Akindolire et al. 2015). The use of antibiotics in the control of such infections is faced with the challenge of resistance of pathogens to antibiotics as a result of misuse/overuse of antibiotics, incorrect dosing, low potency, poor solubility, and lack of quick or accurate tests to diagnose infection (Castro-Sanchez et al. 2016). Consequently, there is a quest for alternative means to surmount this impending danger. Nutrition was an essential component in many traditional forms of medicine (Georgiou et al. 2011), until the last century when its role in curative medicine started to decline. However, following the increased awareness of the importance of lifestyle for disease prevention, we are now facing a reawakening of nutrition or lifestyle in general, for disease management and control (Witkamp and Norren 2018).

A viable option is to opt for safe foods with fewer chemical additives and more natural products which do not deter the organoleptic quality of the food or harm the consumers (Soltani et al. 2021). Biotechnology in the food-processing sector targets the selection, production, and improvement of useful microorganisms and their products, as well as their technical application in food quality and control of foodborne diseases. Generally, food with no additives is more desirable, but if not available, consumers will choose foods containing natural additives over synthetic equivalents (Coderoni and Perito 2020; Perito et al. 2020). Bacteriocins produced by lactic acid bacteria are of interest since they are safe, active in a nanomolar range, heat stable, readily digested by gastric enzymes, and there are currently no reports of pathogenic bacteria developing antimicrobial resistance to them. Effective application in food preservation has been reported and to date no toxic effect has been attributed to their usage. Bacteriocins are multifunctional, ribosomally produced, proteinaceous substances produced by bacteria that are biologically active with antimicrobial action against other bacteria, principally closely related species. They are not usually called antibiotics to avoid confusion with therapeutic drugs, which can cause adverse responses in people with certain medical conditions (Deraz et al. 2005; Negash and Tsehai 2020). Bacteriocins are proteinaceous agents readily degraded by proteases in the human gastrointestinal tract, unlike most therapeutic antibiotics. Antibiotics are secondary metabolites, which are inhibitory agents in low concentrations, excluding inhibition induced by metabolic by-products like organic acids, ammonia, and hydrogen peroxide. Most, if not all, bacteria can create a diverse array of chemicals that may be inhibitory to themselves or to other bacteria during their growth in vitro (and presumably also in their natural habitats) (Ayivi et al. 2020). Bacteriocin synthesis could be advantageous for food and feed manufacturers since these peptides can kill or inhibit pathogenic bacteria that compete for the same ecological niche or nutrient pool when used in adequate levels (Bello et al. 2018). The fact that many bacteriocins have a narrow host range suggests that they are best effective against bacteria with similar nutritional demands for the same limited resources (Yang et al. 2018). Bacteriocins are frequently thought to be more natural because they are believed to have been present in many foods since antiquity. Bacteriocins are inactivated by enzymes, such as trypsin and pepsin, found in the gastrointestinal tract and therefore do not alter the microbiota of the digestive tract (Negash and Tsehai 2020). Although antimicrobial peptides have a narrower inhibition spectrum than antibiotics, the bacteriocins produced by LAB have been reported to infiltrate Gram-negative bacteria's outer membrane and cause inactivation when combined with other antimicrobial environmental factors such as organic acid, low temperature, and detergents (Parada et al. 2007). Bacteriocins are named by the genus or species of the strain that produces them. Lactobacillus plantarum (plantaricin), Lactococcus spp. (lacticin, nisin), and Carnobacterium spp. (carnocin), Enterococcus spp. (enterocin) Leuconostoc spp. (leucocin), and Pediococcus spp. (pediocin) are only a few examples (Yusuf 2013). LAB are Gram-positive, non-spore-forming rods, non-aerobic but aero-tolerant cocci and cocco-bacilli that can ferment carbohydrates into energy and lactic acid (Jay 2000). Firmicutes is the phylum in which LAB is found. The different major genera of LAB include Carnobacterium, Lactobacillus, Lactococcus, Enterococcus, Lactosphaera, Leuconostoc, Melissococcus, Oenococcus, Pediococcus, Streptococcus, Weissella, Vagococcus, and Tetragenococcus. Other genera include Aerococcus, Propionibacterium, Microbacterium, and Bifidobacterium. However, based on a recent study, reclassification of the genus Lactobacillus into 25 genera was proposed, these includes Lactobacillus delbrueckii group, Paralactobacillus, Acetilactobacillus, Agrilactobacillus, Amylolactobacillus, Apilactobacillus, Bombilactobacillus, Companilactobacillus, Dellaglioa, Fructilactobacillus, Furfurilactobacillus, Holzapfelia, Lacticaseibacillus, Lactiplantibacillus, Lapidilactobacillus, Latilactobacillus, Lentilactobacillus, Levilactobacillus, Liquorilactobacillus, Ligilactobacillus, Limosilactobacillus, Loigolactobacilus, Paucilactobacillus, Schleiferilactobacillus, and Secundilactobacillus (Zheng et al. 2020). They are known to constitute the highest percentage of bacteria that display probiotic properties. 
Among compounds produced by LAB during lactic acid fermentations are organic acids, diacetyl, hydrogen peroxide, and bacteriocins or bactericidal proteins (Yusuf 2013).

These microorganisms are ubiquitous in nature; they were first discovered in milk (Carr et al. 2002). They are also found in meat, fermented products, fermented vegetables, and beverages (Gomez-Gallego et al., 2016; Bello et al. 2016). They are also readily available in local food condiments such as fufu, gari, kunu, nono, and ogi commonly consumed in Nigeria and some African countries (Nwaiwu et al. 2020). Fufu is a solid meal of soaked fermented cassava roots while gari is a granular starchy food made from the bitter variety of cassava root. Traditional Ogi preparation is done by soaking maize, millet, or sorghum in water for a day or two, followed by wetmilling, wet-sieving, and fermentation for 2-3 days. Similarly, Nono and kunu are drinks obtained from fermented cow milk and whole grains of millet, sorghum, or corn respectively (Egwim et al. 2013).

Humans and some other animals also harbor LAB (Amarantini et al. 2019) without causing disease in them. Thus, because of the incidence of foodborne diseases in humans and growing resistance of pathogens to most antibiotics, this study aimed to isolate and identify LAB and screen their bioactive properties against food-associated antibiotic-resistant bacteria.

\section{Materials and methods}

\section{Isolation and identification of lactic acid bacteria}

Fermented food samples (fufu, gari, kunu, nono, and ogi) were purchased from local vendors for this study. Serial dilution and pour plate procedures were utilized in the evaluation of the culturable LAB flora of these fermented food samples using commercially available De Mann, Rogosa, and Sharpe (MRS, Oxoid, Fisher Scientific) agar. Six blanks were prepared by pipetting $9 \mathrm{ml}$ of distilled water in 6 macCartney bottles, corking them and sterilizing for serial dilution from $10^{-1}$ to $10^{-6}$. Pour plate technique was carried out in plating $0.1 \mathrm{ml}$ of dilution $10^{-3}, 10^{-5}$, and $10^{-6}$ on each of De Mann Rogosa Sharpe (MRS) agar. After incubation at $37{ }^{\circ} \mathrm{C}$ for $48 \mathrm{~h}$ under anaerobic conditions, discrete colonies that developed were counted and recorded (Putria et al. 2020; Vantsawa et al. 2017). Isolated colonies with cultural characteristics, namely, raised, off-white, spherical small with entire margins were picked from each plate and transferred to MRS broth for further analysis. The strain identification was made using the standard morphological, physiological, biochemical, and molecular assays (Kim and Kim 2014; Islam et al. 2016).

\section{Bacteriocin assay}

The inhibitory activity of the selected LAB isolates against Escherichia coli ATCC 25922 and Staphylococcus aureus ATCC 25923, which were used as indicator organisms, was assayed by the agar spot test. The LAB isolates were spotted onto the surface of the MRS agar and incubated at $32{ }^{\circ} \mathrm{C}$ for $24 \mathrm{~h}$ to allow colonies to develop. Sterile water $(5 \mathrm{ml})$ was seeded with the indicator organism and poured into $50 \mathrm{ml}$ of soft nutrient agar $(0.9 \%$ agar) to get a concentration of $1.5 \times 10^{8}$ bacterial suspension per ml. This was then cooled to about $45{ }^{\circ} \mathrm{C}$ to prevent cell death. This was mixed by rotating the flask between two hands; the contents were gently overlaid onto each plate on which the LAB isolates were grown and allowed to cover the cultured agar plate surface entirely and left to solidify. After incubation at $32{ }^{\circ} \mathrm{C}$ for 24 $h$ under anaerobic conditions, the plates were examined for the presence of inhibition zones. Inhibition was considered positive when the inhibition halo of the indicator strain above the LAB colonies was more than $2 \mathrm{~mm}$ (Hockett and Baltrus 2017).

\section{Production and antimicrobial assay of the cell-free supernatant (CFS) obtained from LAB broth culture} The strains of the selected LAB isolates, which showed the inhibition zone, were used for further studies. The cell-free supernatants were prepared based on methods described by Mariam et al. (2014) with a little modification. The producer strains' culture extract was obtained from 18-24 h culture grown on MRS broth. The cultures were then centrifuged at 10,000 rpm for $15 \mathrm{~min}$ (Hettich EBA 85 Tutthugen, made in Germany). The inhibitory activity against the indicator organisms was assayed by the agar well-diffusion test (Valgas et al. 2007). Nutrient agar was inoculated with $1 \mathrm{ml}$ of sterile water seeded with $18 \mathrm{~h}$ culture of indicator bacteria (E. coli or S. aureus). This was spread using a hockey stick to cover the surface of the agar and allowed to diffuse. Wells $(5 \mathrm{~mm}$ in diameter) were cut into the agar using a sterile cork borer and filled with the cell-free supernatant (CFS) obtained from each LAB isolate. After incubation at $32{ }^{\circ} \mathrm{C}$ for $24 \mathrm{~h}$, the plates were examined for the presence of inhibition zones. Inhibition was considered positive when the width of the clear zone around the wells was $0.5 \mathrm{~mm}$ or larger (Balouiri et al. 2016).

\section{Confirmation of the bacteriocinogenic nature of the inhibitory substances}

To confirm the bacteriocinogenic nature of the inhibitory substances produced by the putative bacteriocinproducing strains, additional tests were performed to exclude the effect of organic acids, hydrogen peroxide, and to confirm the proteinaceous nature of the 
inhibitory substance and its bactericidal mode of action according to the techniques described below.

\section{Elimination of the effect of organic acids and hydrogen peroxide as inhibitory agents}

The effect of organic acid was eliminated by adjusting the $\mathrm{pH}$ of the supernatants to 7.0 with $1 \mathrm{M} \mathrm{NaOH}$. The supernatant was then filter-sterilized using a membrane filtration unit with a $0.2-\mu \mathrm{m}$ pore size millipore filter and subjected to agar well diffusion assay.

To exclude the action of hydrogen peroxide, $18 \mathrm{~h}$ cultures of strains showing antimicrobial activity after acid neutralization was diluted at a ratio of 1:10 mM Tris $\mathrm{HCl}\left(\mathrm{pH} \mathrm{7.0)}\right.$ and $2 \mu \mathrm{l}$ of the suspension (about $10^{6}$ cells $/ \mathrm{ml}$ ) was inoculated on Rogosa SL agar in culture plate and incubated. Eight-hour growing cultures of indicator organisms were diluted at a 1:10 ratio in $10 \mathrm{mM}$ Tris $\mathrm{HCl}(\mathrm{pH}$ 7.0) and mixed with Rogosa SL soft agar $\left(48^{\circ} \mathrm{C}\right)$. Catalase enzyme was added at a final concentration of $0.5 \mathrm{mg} / \mathrm{ml}$. The mixture was poured onto the culture plate wells; one well having no catalase enzyme served as the control. The final culture plates were examined after 18-24 $\mathrm{h}$ of incubation. The presence of an inhibition zone around wells both with and without catalase was observed and was determined to be the effect of bacteriocin (Tatsinkou et al. 2017; Voidarou et al. 2020).

\section{Optimization assay}

The selected strain of LAB was subjected to different culture conditions to derive the optimum conditions for bacteriocin production in MRS broth (Todorov and Dicks 2004). Growth and bacteriocin production were estimated at temperatures $20{ }^{\circ} \mathrm{C}, 30{ }^{\circ} \mathrm{C}, 40{ }^{\circ} \mathrm{C}, 50{ }^{\circ} \mathrm{C}$, and $60{ }^{\circ} \mathrm{C}, \mathrm{pH} 4.0,5.0,6.0,7.0$, and 8.0 and $\mathrm{NaCl}$ concentrations $1.0 \%, 1.5 \%, 2.0 \%, 2.5 \%$, and $3.0 \%$. The absorbance of the broth culture was taken at a wavelength of 620 $\mathrm{nm}$ using Jenway spectrophotometer (Todorov and Dicks 2004; Benmouna et al. 2018).

\section{Purification of bacteriocin}

The cell-free supernatant was subjected to ammonium sulfate fractionation. On centrifugation at 10,000 rpm and temperature of $4{ }^{\circ} \mathrm{C}$ for $10 \mathrm{~min}$, the pellets were collected and resuspended in a minimal volume of $0.2 \mathrm{ml}$ Tris-HCl buffer pH 7.0 (Karthikeyan and Santosh 2009). A dialysis tube was treated to remove protectants such as sulfur or glycerin compounds present in it. The protein content of the CFS was determined following the protocol described by Lowry et al. (1951).

\section{Molecular weight determination of purified bacteriocins} The molecular weight of purified bacteriocin was estimated using sodium dodecyl sulfate-polyacrylamide gel electrophoresis (SDS-PAGE) to characterize the bacteriocins. Gels were stained with coomassie brilliant blue R-250 after electrophoresis. The molecular weights of the bacteriocins were then estimated using a protein ladder of 170-10 kDa (Hassan et al. 2020).

\section{Antibiotics sensitivity pattern of isolated foodborne pathogens}

Antibiotics sensitivity test was conducted on pathogenic strains of Bacillus subtilis, Klebsiella pneumonia, and Salmonella typhimurium obtained from a minced pie. Nutrient agar was inoculated with $1 \mathrm{ml}$ of sterile water seeded with $18 \mathrm{~h}$ culture of isolated foodborne pathogens. This was spread using a hockey stick to cover the surface of the agar and allowed to diffuse. Antibiotics disc containing ampicillin $(10 \mu \mathrm{g})$, ampiclox $(30 \mu \mathrm{g})$, augmentin $(30 \mu \mathrm{g})$, amoxycilin $(25 \mu \mathrm{g})$, cefuroxime (30 $\mu \mathrm{g})$, ceftriaxone, chloramphenicol $(30 \mu \mathrm{g})$, ciprofloxacin $(5 \mu \mathrm{g})$, cotrimoxazole $(25 \mu \mathrm{g})$, erytromycin $(5 \mu \mathrm{g})$, gentamicin $(10 \mu \mathrm{g})$, ofloxacin $(5 \mu \mathrm{g})$, pefloxacin $(5 \mu \mathrm{g})$, and streptomycin $(10 \mu \mathrm{g})$, were placed on the agar surface using sterile forceps. Zone of inhibition was read after $24 \mathrm{~h}$ of incubation at $35^{\circ} \mathrm{C}$ and recorded (Balouiri et al. 2016).

Determination of antibacterial susceptibility and mode of inhibitory action of the cell-free supernatant (CFS) against the antibiotics resistant foodborne pathogens

Eight-hour growing culture of antibiotic-resistant foodborne pathogenic organisms were diluted at a 1:10 ratio in $10 \mathrm{mM}$ Tris $\mathrm{HCl}(\mathrm{pH} \mathrm{7.0)}$ and mixed with molten nutrient agar $\left(48^{\circ} \mathrm{C}\right)$. Catalase enzyme was added at a final concentration of $0.5 \mathrm{mg} / \mathrm{ml}$. The mixture was swirled to ensure even distribution and poured onto the culture plate and allowed to solidify. A well with a diameter of 6 to $8 \mathrm{~mm}$ was punched aseptically with a sterile cork borer, and a volume $(1 \mathrm{ml})$ of the neutralized cell-free supernatant (NCFS) was introduced into the well using sterile pipette tips. The plates were incubated at $37^{\circ} \mathrm{C}$ for $24 \mathrm{~h}$ after which they were observed for zones of inhibition, and the diameter was noted. Inhibition was positive when the inhibition halo around the well was more than $2 \mathrm{~mm}$ (Amarantini et al. 2019).

\section{Estimation of bacteriocin concentration}

The concentration of bacteriocin in the CFS was quantified using Lowry's method. One $\mathrm{mL}$ of the bacteriocin solution was mixed with $1.4 \mathrm{~mL}$ of Lowry solution. This was shaken and incubated in the dark at room temperature. After $20 \mathrm{~min}$ of incubation, $1.3 \mathrm{~mL}$ of the suspension was collected while $0.1 \mathrm{~mL}$ diluted Folin reagent was added, mixed thoroughly and incubated under the same condition for $30 \mathrm{~min}$. The absorbance reading was taken at $650 \mathrm{~nm}$. Extract concentration was 
Table $1 \mathrm{pH}$ values and total viable LAB counts (cfu/ml) of fermented food samples

\begin{tabular}{lll}
\hline Food sample & $\mathbf{p H}$ & $\begin{array}{l}\text { Mean LAB count } \\
\left(\times 10^{5} \mathbf{c f u} / \mathbf{g} \text { or } \mathbf{c f u} / \mathbf{m l}\right)\end{array}$ \\
\hline Fufu & $3.6^{\mathrm{ac}}$ & $3.19 \pm 0.16^{\mathrm{a}}$ \\
Gari & $4.6^{\mathrm{b}}$ & $0.04 \pm 0.02^{\mathrm{b}}$ \\
Kunu & $3.9^{\mathrm{ab}}$ & $55.90 \pm 0.99^{\mathrm{c}}$ \\
Nono & $2.8^{\mathrm{c}}$ & $0.07 \pm 0.02^{\mathrm{b}}$ \\
Ogi & $3.8^{\mathrm{ab}}$ & $55.50 \pm 1.80^{\mathrm{c}}$ \\
\hline
\end{tabular}

Key: Same alphabets in superscript across column indicate no significant difference $(p>0.05)$

extrapolated from the standard curve prepared using bovine serum albumin (Lowry et al. 1951).

\section{Molecular identification of the bacteriocin- producing lactic acid bacteria}

Chromosomal DNA extraction was done using MP Biomedicals fast spin kit for soil following the manufacturer's protocol.

The characterization at the molecular level was done using DNA extraction and PCR amplification with the aid of LAB specific primer, which included 10F (10F AGTTTGATCATGGCTCAGATTG) and 1507R (TACC TTGTTACGACTTCACCCCAG) as well as 27F (GAGAGTTTGATCCTGGCTCAG) and 1492R (GGTT
ACCTTGTTACGACTT). DNA extraction was carried out on the cell suspensions with an $\mathrm{OD}_{600}$ of 2.0 in 100 $\mu \mathrm{l}$ (Prosekov et al. 2013).

\section{Agarose gel electrophoresis}

Five microliters of each PCR product was electrophoresed on $1.5 \%(\mathrm{w} / \mathrm{v})$ agarose gel at 110 volts for $45 \mathrm{~min}$. The gels were thereafter stained in ethidium bromide for $10 \mathrm{~min}$ and de-stained in clean water for $20 \mathrm{~min}$, after which they were viewed under ultraviolet (UV) light with the aid of a transilluminator.

\section{Sequencing of PCR amplicons}

The remaining amplicons from PCR (after gel electrophoresis) were transferred from PCR tubes into appropriately labeled sterile Eppendorf tubes. The tubes were frozen at $-20{ }^{\circ} \mathrm{C}$ in freezer boxes before transportation for sequencing. The amplicons were purified using a DNA purification kit and after that sequenced with the Sanger method by Inqaba Biotech Company using the 27F $16 \mathrm{~S}$ rRNA primer.

\section{Sequence analysis and identification of isolates}

The obtained 16S rRNA sequences were analyzed using the Basic Local Alignment Search Tool (BLAST) (Zhang et al. 2000) version 2.6.0+ tool of the NCBI

Table 2 Inhibitory activity of selected lactic acid bacteria strains against bacterial indicator strains after eliminating effect of organic acid and $\mathrm{H}_{2} \mathrm{O}_{2}$ by using agar well diffusion method

\begin{tabular}{|c|c|c|c|c|c|}
\hline \multirow{2}{*}{$\begin{array}{l}\text { Test } \\
\text { isolate }\end{array}$} & \multicolumn{5}{|l|}{ Sensitivity } \\
\hline & Staphylococcus aureus & Escherichia coli & Leuconostoc mesenteroides & Salmonella typhimurium & Bacillus cereus \\
\hline $\mathrm{K}_{2} 45$ & - & - & - & - & - \\
\hline $\mathrm{K}_{2} 5$ & ++ & ++ & ++ & ++ & ++ \\
\hline $\mathrm{K}_{1} 7$ & ++ & ++ & + & + & ++ \\
\hline $\mathrm{K}_{1} 20$ & ++ & ++ & ++ & + & ++ \\
\hline $\mathrm{K}_{1} 35$ & ++ & ++ & ++ & ++ & ++ \\
\hline N4 & ++ & ++ & ++ & ++ & ++ \\
\hline $\mathrm{K}_{2} 46$ & - & - & - & - & - \\
\hline $\mathrm{K}_{2} 28$ & - & - & - & - & - \\
\hline$O_{1 D}$ & ++ & ++ & ++ & + & ++ \\
\hline $\mathrm{O}_{2 \mathrm{E}}$ & - & - & - & - & - \\
\hline $\mathrm{O}_{3 \mathrm{~F}}$ & - & - & - & - & - \\
\hline N5 & ++ & - & - & - & - \\
\hline G5 & ++ & - & - & - & - \\
\hline F4 & - & - & - & - & - \\
\hline K10 & ++ & ++ & ++ & ++ & ++ \\
\hline K11 & ++ & ++ & ++ & ++ & ++ \\
\hline N14 & ++ & ++ & ++ & ++ & ++ \\
\hline
\end{tabular}

$K$ kunu, $O$ ogi, $N$ nono, $G$ gari, $F$ fufu

$*_{++}>15 \mathrm{~mm}$ zone of inhibition

$+<15 \mathrm{~mm}$ zone of inhibition

- Not sensitive 


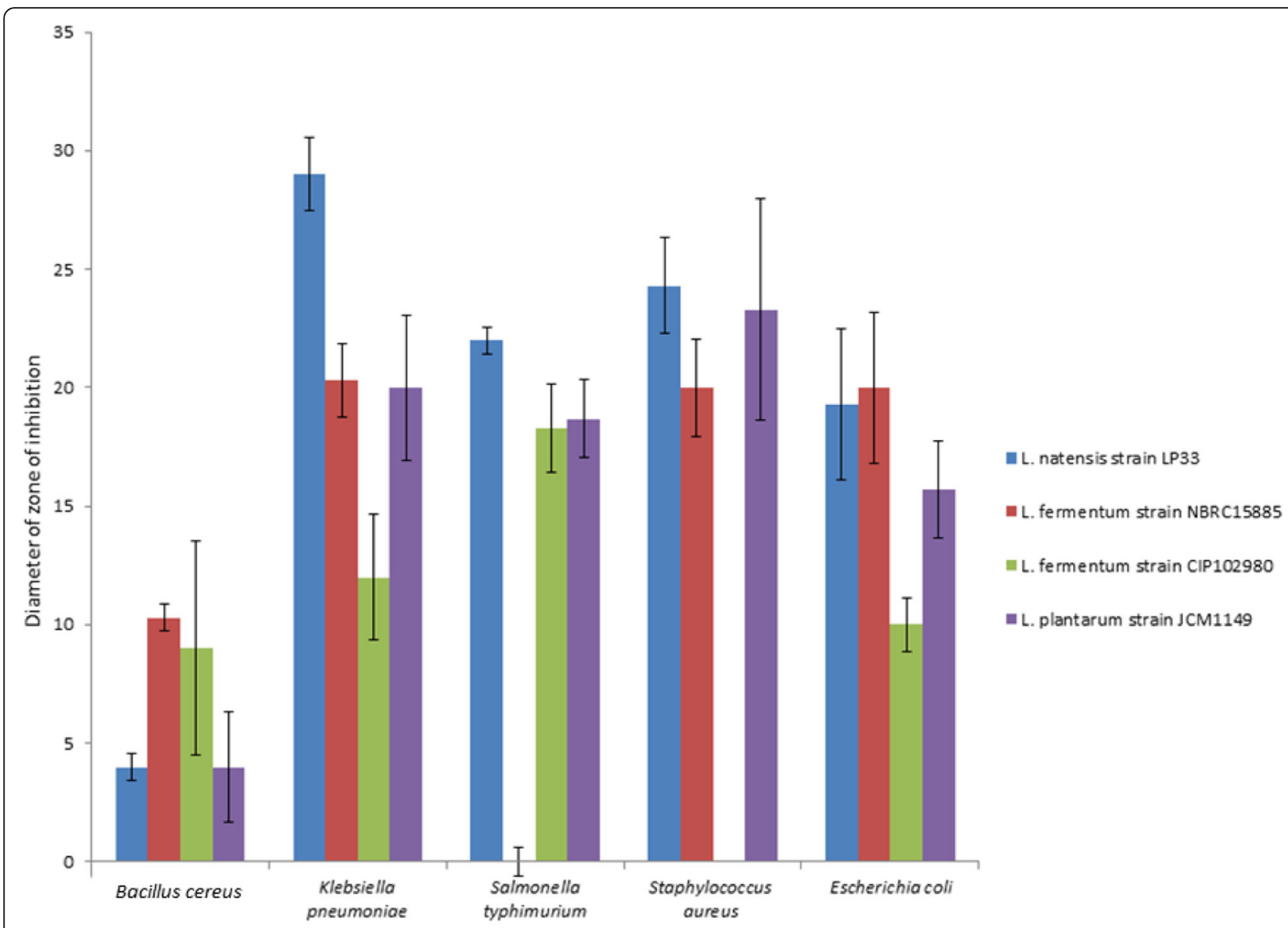

Fig. 1 Antibacterial susceptibility of foodborne pathogens to LAB bacteriocin. Values are the mean of three experiments and error bars represent standard deviation

(National Center for Biotechnology Information) database. The database employed was $16 \mathrm{~S}$ rRNA sequences, while the program selection was set to optimize for highly similar sequences (megaBLAST). The BLAST was run for each $16 \mathrm{~S}$ rRNA sequence. An optimized BLAST, in which low-quality nucleotide bases, which usually occur at the beginning and end of sequence are deleted, was run in each case to confirm the identity of each sequence further. Strains with sequences that were 97\% identical to the database match were presumed to belong to the same species as the matching organism in the database, and a 95\% cut-off was used to define genera (Kim et al. 2014).

\section{Multiple sequence alignment and phylogenetic analysis}

The 16S rRNA gene sequence was compared with sequences from the NCBI database by BLAST analysis (http://www.ncbi.nlm.nih.gov/BLAST) as well as with sequences available at the EZTaxon database (www. ezbiocloud.net/) (Yoon et al. 2017). The 16S-based ID isolation of bacterial isolate using the 16S rRNA sequences option was selected. Comparison of the $16 \mathrm{~S}$
rRNA gene sequence was done for each strain while the strains with the highest similarity were used for phylogenetic tree construction. The evolutionary history was inferred following the recommendation from the recent re-evaluation of the taxonomy of Lactobacillaceae and Leuconostocaceae (Zheng et al. 2020).

\section{Statistical analysis}

All the assays were done in triplicates. Analysis of variance and descriptive statistics were employed to examine the data gotten from the study using Statistical Package for the Social Sciences ${ }^{\circ}$ version 21, PAST version $2.17 \mathrm{c}$ and Microsoft Excel version 2010 (Ogbeibu 2005).

\section{Results}

Determination of the $\mathrm{pH}$ of the fermented food samples and isolation of $L A B$

Table 1 shows the $\mathrm{pH}$ values of the fermented food samples, the highest $\mathrm{pH}$ value was recorded for gari with a $\mathrm{pH}$ of 4.2, while $\mathrm{kunu}$ had the lowest $\mathrm{pH}$ with a value of 3.1. Fufu had $\mathrm{pH}$ values of 3.8 while nono and ogi had a $\mathrm{pH}$ of 3.6. The colony count of the LAB isolated from 


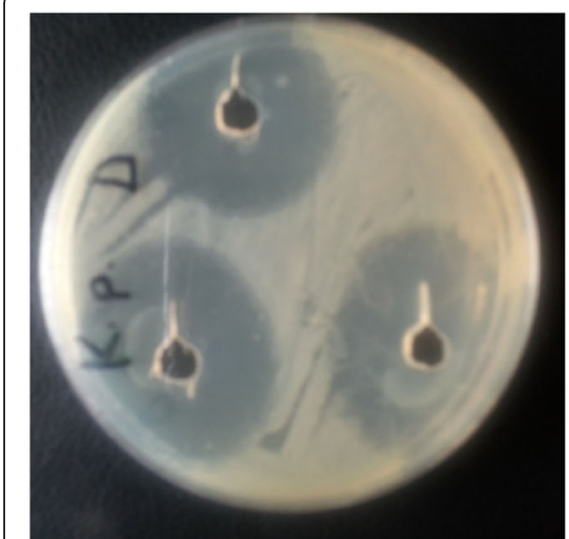

A: Antibacterial activity of $L$. natensis bacteriocin against Klebsiella pneumoniae

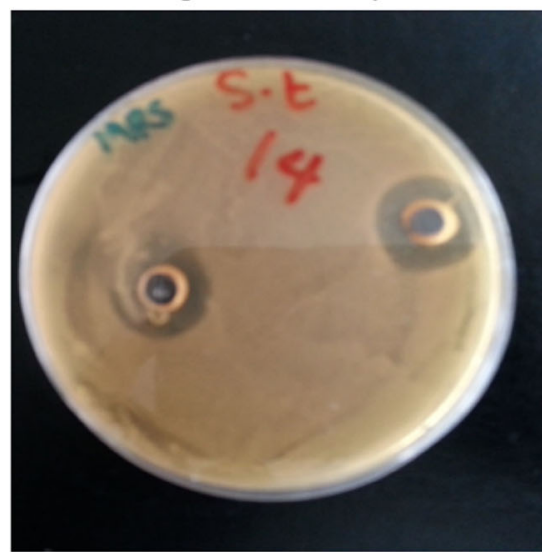

D: Antibacterial activity of $L$. plantarum bacteriocin against $S$. aureus

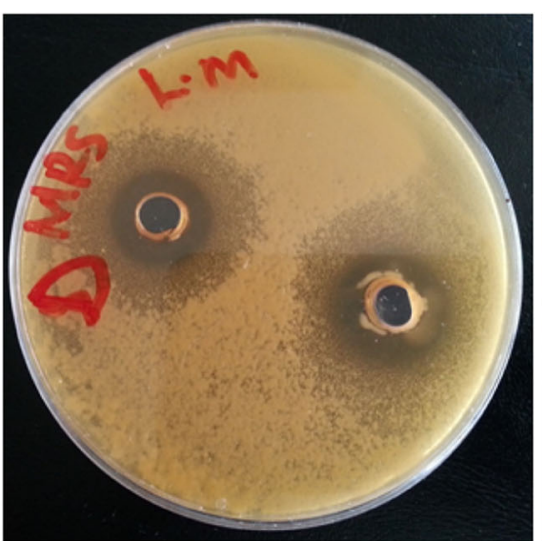

B: Antibacterial activity of L. natensis bacteriocin against Leuconostoc mesenteroides

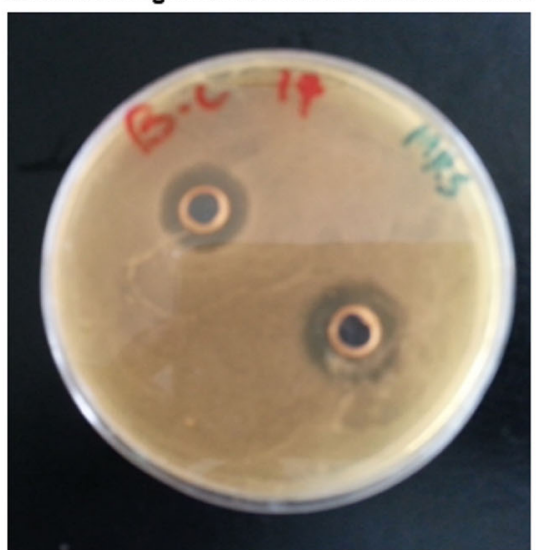

E: Antibacterial activity of L. plantarum bacteriocin against Bacillus cereus

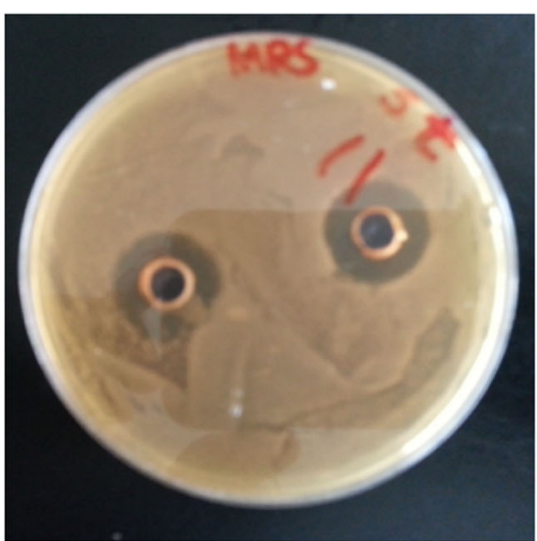

C: Antibacterial activity of $L$. fermentum bacteriocin against Salmonella typhimurium

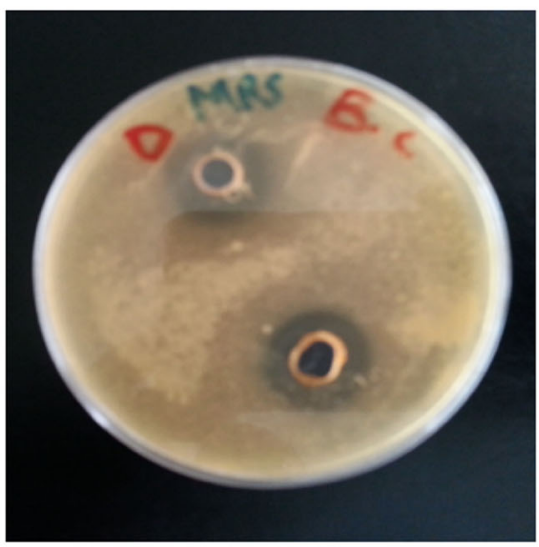

F: Antibacterial activity of L. natensis bacteriocin against Bacillus cereus

Plate 1 Antimicrobial activity of selected lactic acid bacteria bacteriocin against food associated antibiotic resistant bacteria

the fermented food samples is shown in Tables 1 and 2 . The total viable count varied for the different food samples. The highest LAB count was observed in kunu samples, followed by ogi, fufu, and nono while gari had the lowest count. The kunu samples had an average count of $5.60 \pm 0.10 \times 10^{6} \mathrm{cfu} / \mathrm{ml}$ and $3.38 \pm 0.21 \times 10^{7} \mathrm{cfu} / \mathrm{ml}$ for the third and fourth dilution, respectively. Ogi had a count of $5.55 \pm 0.18 \times 10^{6} \mathrm{cfu} / \mathrm{g}$ and $3.43 \pm 0.11 \times 16^{6} \mathrm{cfu} / \mathrm{g}$ for the second and third dilutions. The first two dilutions for kunu had a growth that was too numerous to count. For fufu, the total plate counts for the second and third dilutions were $3.19 \pm 0.16 \times 10^{5} \mathrm{cfu} / \mathrm{g}$ and $7.07 \pm 0.75 \times 16^{5}$ $\mathrm{cfu} / \mathrm{g}$. No growth was observed in the third and fourth dilutions of nono and gari. However, the first and second dilutions had an average count of $2.23 \pm 0.6 \times 10^{3} \mathrm{cfu} / \mathrm{ml}$ and $6.50 \pm 2.5 \times 10^{3} \mathrm{cfu} / \mathrm{ml}$ for nono and $1.30 \pm 0.6 \times 10^{3}$ $\mathrm{cfu} / \mathrm{ml}$ and $2.30 \pm 1.86 \times 10^{3} \mathrm{cfu} / \mathrm{g}$ for gari.

\section{Antimicrobial activity of bacteriocin-producing LAB}

A total of 194 colonies that were Gram-positive and catalase-negative were subjected to overlayed spot agar test to assay for bacteriocin-producing properties using $S$. aureus and E. coli as test organisms for the primary bacteriocin screening process. The number of colonies picked from kunu was 52, with 17 inhibiting the growth of $S$. aureus and 24 colonies were inhibiting the growth of $E$. coli. A total of 32 colonies were picked from ogi, with 8 inhibiting the growth of S. aureus and 14 inhibiting the growth of E. coli. Nono had 61 colonies, 5 inhibited the growth of $S$. aureus and 12 inhibited the growth of $E$. coli. Out of the 51 colonies picked from fufu, $S$. aureus was sensitive to 30 colonies while $E$. coli was sensitive to 20 colonies. A total of 17 colonies were picked from gari sample, with 10 colonies showing a zone of inhibition in overlayed spot agar containing $S$. aureus and 7 colonies showing zone of inhibition in overlayed spot agar containing E. coli. This is shown in Tables 1 and 2.

On neutralization and treatment of the CFS with catalase to exclude the effect of lactic acid and hydrogen peroxide, only 9 isolates could inhibit the growth of $E$. coli ATCC 25922 and S. aureus ATCC 25923. Four of these isolates were also able to inhibit the growth of 


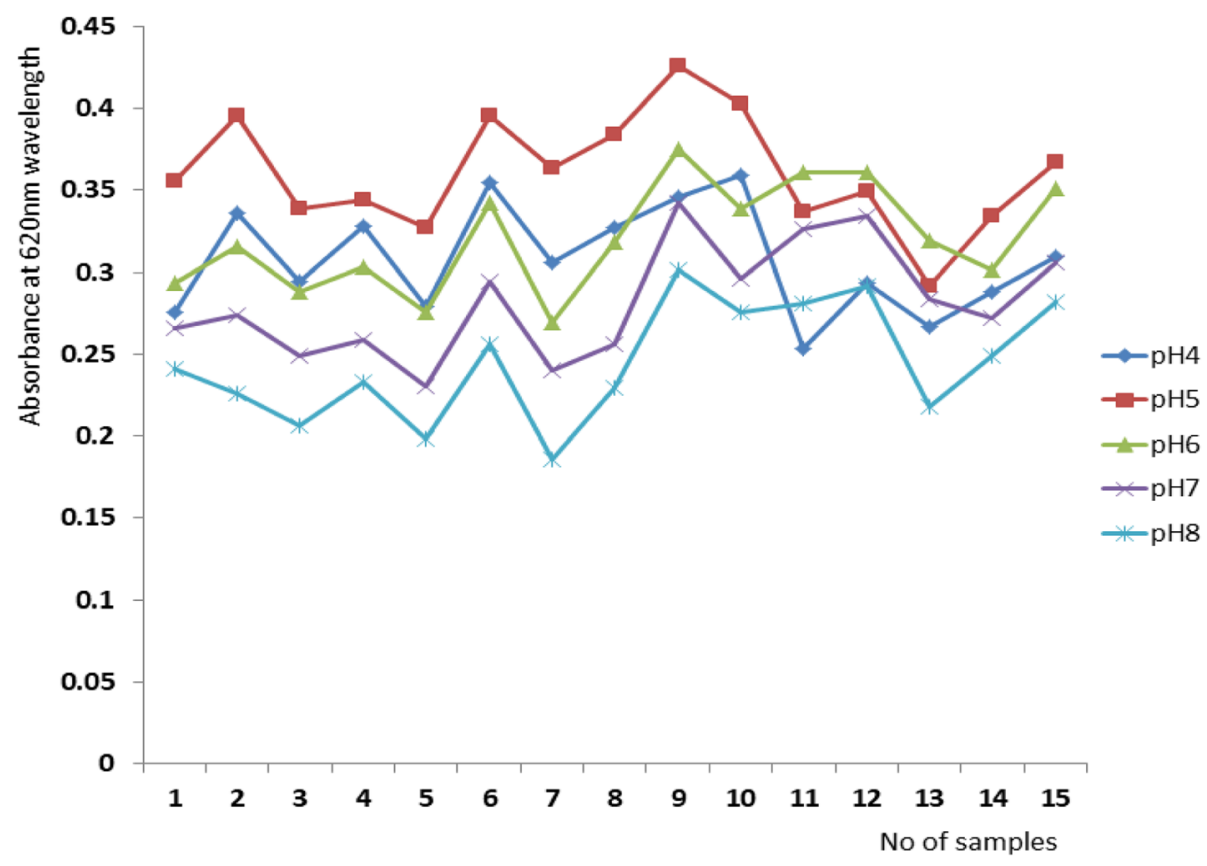

Fig. 2 Optimization assay for pH (absorbance at $620 \mathrm{~nm}$ wavelength)

pathogenic strains of B. subtilis, Klebsiella pneumonia, and S. typhimurium isolated from minced pie (Fig. 1 and Plate 1). These isolates were identified as Lactobacillus fermentum strain NBRC15885, now known as (Limosilactobacillus fermentum NBRC15885), Lactobacillus fermentum strain CIP102980 (Limosilactobacillus fermentum CIP102980), Lactobacillus plantarum strain JCM1149 (Lactiplantibacillus garii JCM1149), and Lactobacillus natensis strain LP33 (Companilactobacillus nantensis LP33).

\section{Confirmation of the bacteriocinogenic nature of the inhibitory substance}

The 9 isolates that displayed notable inhibitory effects against the growth of E. coli ATCC 25922 and S. aureus ATCC 25923 were further tested against Leuconostoc mesenteriodes, Salmonella typhimurium, and Bacillus cereus. They exhibited a varied level of inhibition with $\mathrm{K}_{2} 5, \mathrm{~K}_{1} 25, \mathrm{~K} 10$, and $\mathrm{K} 11$ from kunu and samples N4 and N14 from nono displaying inhibition zone greater than $15 \mathrm{~mm}$. Zone of inhibition more significant than 15 $\mathrm{mm}$ was only observed against Bacillus cereus for sample $\mathrm{K}_{1} 7$, while sample D inhibited the growth of Leuconostoc mesenteriodes and Bacillus cereus to a level greater than $15 \mathrm{~mm}$ (Tables 1 and 2).

\section{Optimization assay for bacteriocin production}

The selected pure LAB culture showed optimal growth in MRS broth with an optimal bactericidal protein production observed at $\mathrm{pH} 5.0$ and $2.5 \% \mathrm{NaCl}$ when cultures were incubated at $40{ }^{\circ} \mathrm{C}$ (Figs. 2, 3, and 4).

Antibiotic sensitivity pattern of test foodborne pathogens B. cereus was resistant to $40 \%$ of the antibiotics and sensitive to $30 \%$ of the antibiotics. The remaining $30 \%$ exhibited an intermediate zone of inhibition. S. aureus exhibited a higher level of resistance of $50 \%$ to the antibiotics, $30 \%$ susceptibility and intermediate inhibition of 30\%. Among the Gram negative organisms, K. pnuemoniae had the highest resistance of $70 \%$ followed by E. coli (60\%) and then S. typhi (40\%). Susceptibility of $30 \%$ was observed for $S$. typhi while K. pnuemoniae and E.coli had susceptibility of $20 \%$ each.

Protein estimation and screening for bacteriocin activity Protein estimation in the dialysate obtained by ammonium sulfate precipitation and dialysis is represented in Fig. 5. When agar well diffusion assay was employed to qualitatively evaluate the fractionate containing the purified bacteriocin, four fractionates inhibited the test organisms' growth.

\section{Molecular phylogeny}

The phylogenetic data were obtained using the EzTaxon database, which includes sequences from type strains and therefore ensured more precise identification of bacterial strains. The four isolates' $16 \mathrm{~S}$ gene sequences were compared to $16 \mathrm{~S}$ gene sequences deposited in the EZTaxon 


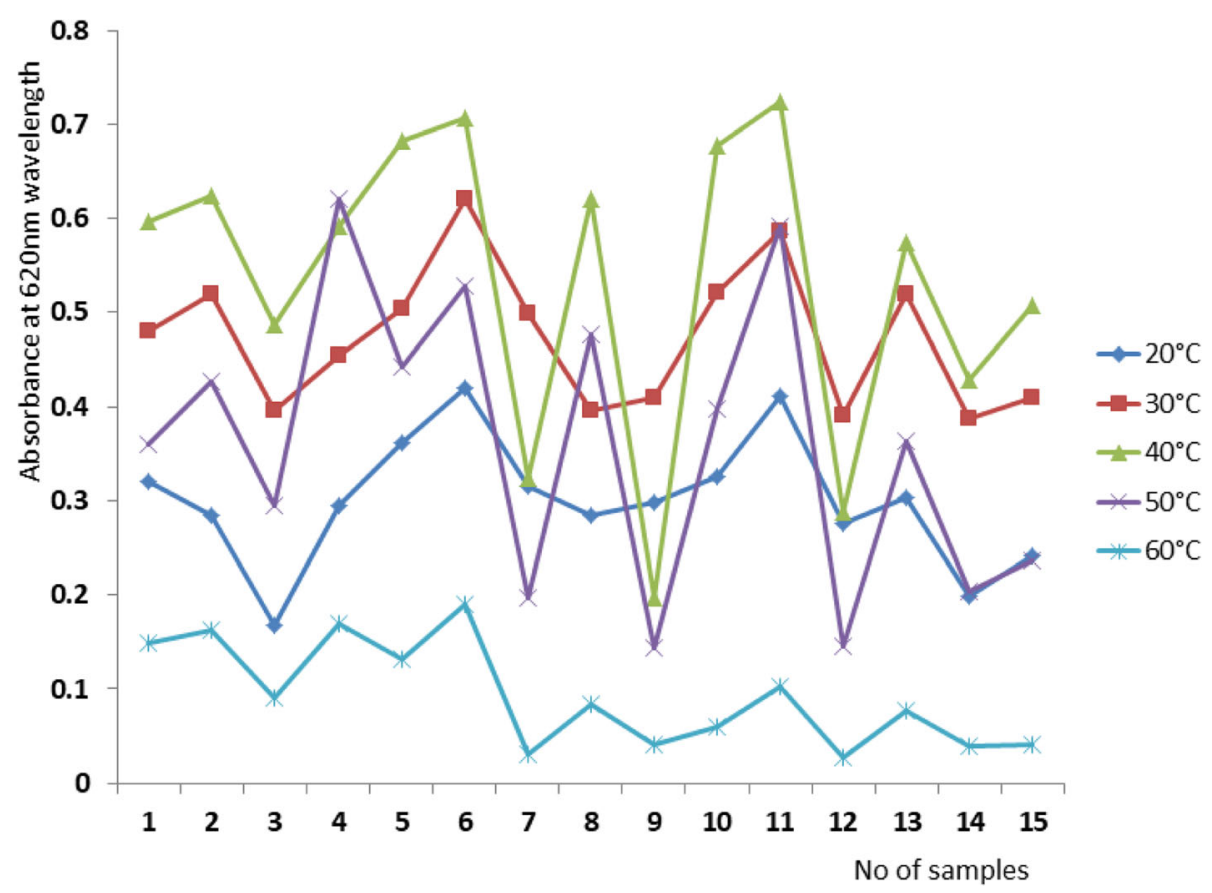

Fig. 3 Optimization assay for temperature (absorbance at $620 \mathrm{~nm}$ wavelength)

database (EZBioCloud.net). Companilactobacillus nantensis LP33, Lactiplantibacillus garii JCM 1149, Limosilactobacillus fermentum CIP 102980, and Limosilactobacillus fermentum NBRC 15885 were the isolates with the most similar 16S rRNA gene sequences. Figure 6 illustrates the evolutionary tree.

\section{Characterization of bacteriocin}

SDS-PAGE is the ideal electrophoretic system for the resolution of proteins smaller than $30 \mathrm{kDa}$. With the aid of this approach, we observed that the molecular weights of the bacteriocins produced by these LAB strains were about $23 \mathrm{kDa}$. Vasilchenko et al. (2018) reported that

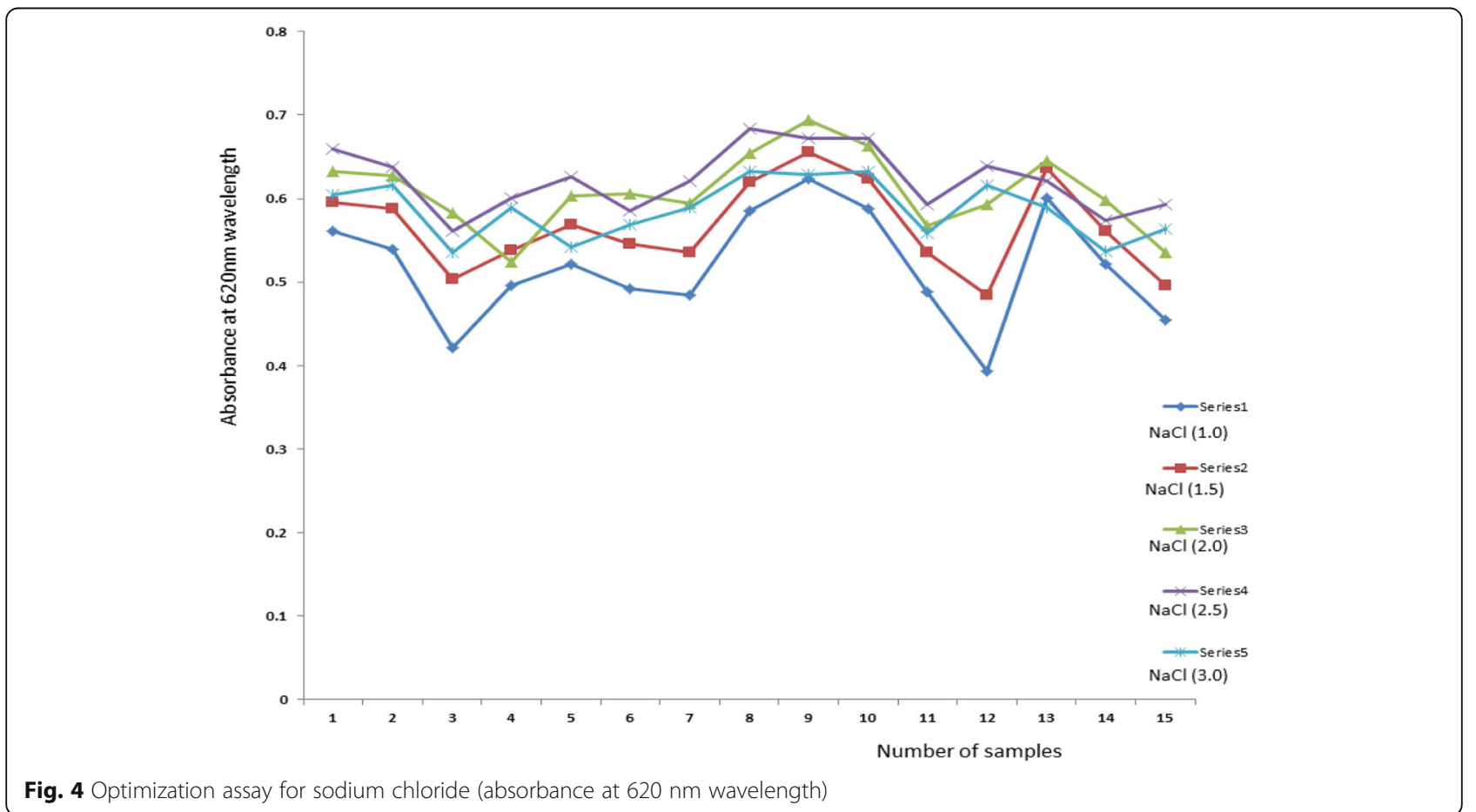




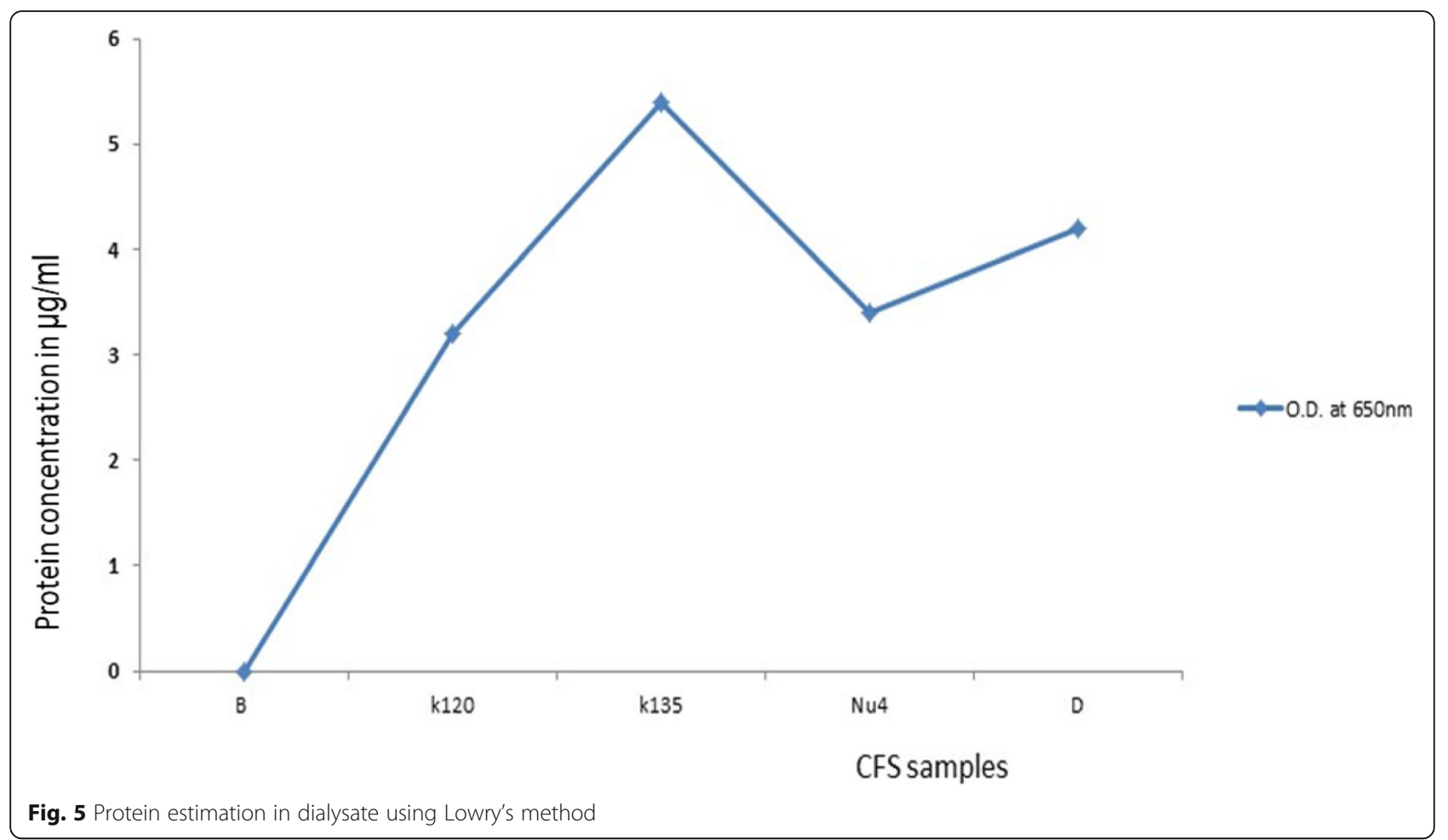

high SDS-PAGE molecular weight result indicates that they belong to class III in bacteriocin classification schemes (Fig. 7).

\section{Discussion}

Consumption of fermented food has become a part of the cultural and traditional norm among the indigenous communities in Nigeria. Different zones in the country have peculiar favorites that have evolved over centuries, depending on the customs, tradition, and religion of the people. Worthy of note is that these fermented foods are rich in LAB, which possess probiotic properties. Interestingly, local non-alcoholic beverages like nono and kunu are preferred to carbonated drinks by consumers. However, the frequency of consumption appeared to be low (Dada and Awotunde 2017).

The present investigation highlights LAB's isolation, characterization, and identification from fufu, kunu, nono, and gari. The total LAB count was in the following order: kunu $>$ fufu $>$ nono $>$ gari. The lowest count was observed for gari due to the low water activity and the production process; this is similar to the findings of Ayodeji et al. (2017). In addition, the $\mathrm{pH}$ of all the food samples was low; this is in line with the findings of Imade et al. (2013) that reported a reduction in $\mathrm{pH}$ as a result of fermentation. The organisms isolated from these fermented food samples are Lactobacillus fermentum strain NBRC15885 now known as (Limosilactobacillus fermentum NBRC 15885) and Lactobacillus fermentum strain CIP102980 (Limosilactobacillus fermentum CIP102980) from kunu, Lactobacillus plantarum strain JCM1149 (Lactiplantibacillus garii JCM1149) from nono, and Lactobacillus nantensis strain LP33 (Companilactobacillus nantensis LP33) from ogi. The genus Lactobacillus comprises species that are very important and beneficial to man. As at March 2020, about 261 species that are dissimilar at ecological, genotypic and phenotypic levels had been identified. This necessitated the re-evaluation of the taxonomy of Lactobacillaceae and Leuconostocaceae on the basis of whole-genome sequences. Based on the findings of the study, reclassification of the genus Lactobacillus into 25 genera was proposed; this is responsible for the change in the generic name from Lactobacillus to the respective new names represented above (Zheng et al. 2020).

CFS containing crude bacteriocin was obtained from the isolated LAB. This CFS was tested for antimicrobial susceptibility to a spectrum of foodborne antibiotic resistant Gram-positive and Gram-negative bacteria commonly known to be associated with various clinical manifestations by agar well diffusion method. The highest inhibitory activity was demonstrated by bacteriocins produced by Lactobacillus natensis strain LP33 against Klebsiella pneumoniae. Also, worthy of note is the inhibitory effect of the bacteriocins produced by Lactobacillus fermentum strain NBRC15885, Lactobacillus fermentum strain CIP102980, and Lactobacillus plantarum strain JCM1149. The CFS from the broth culture 


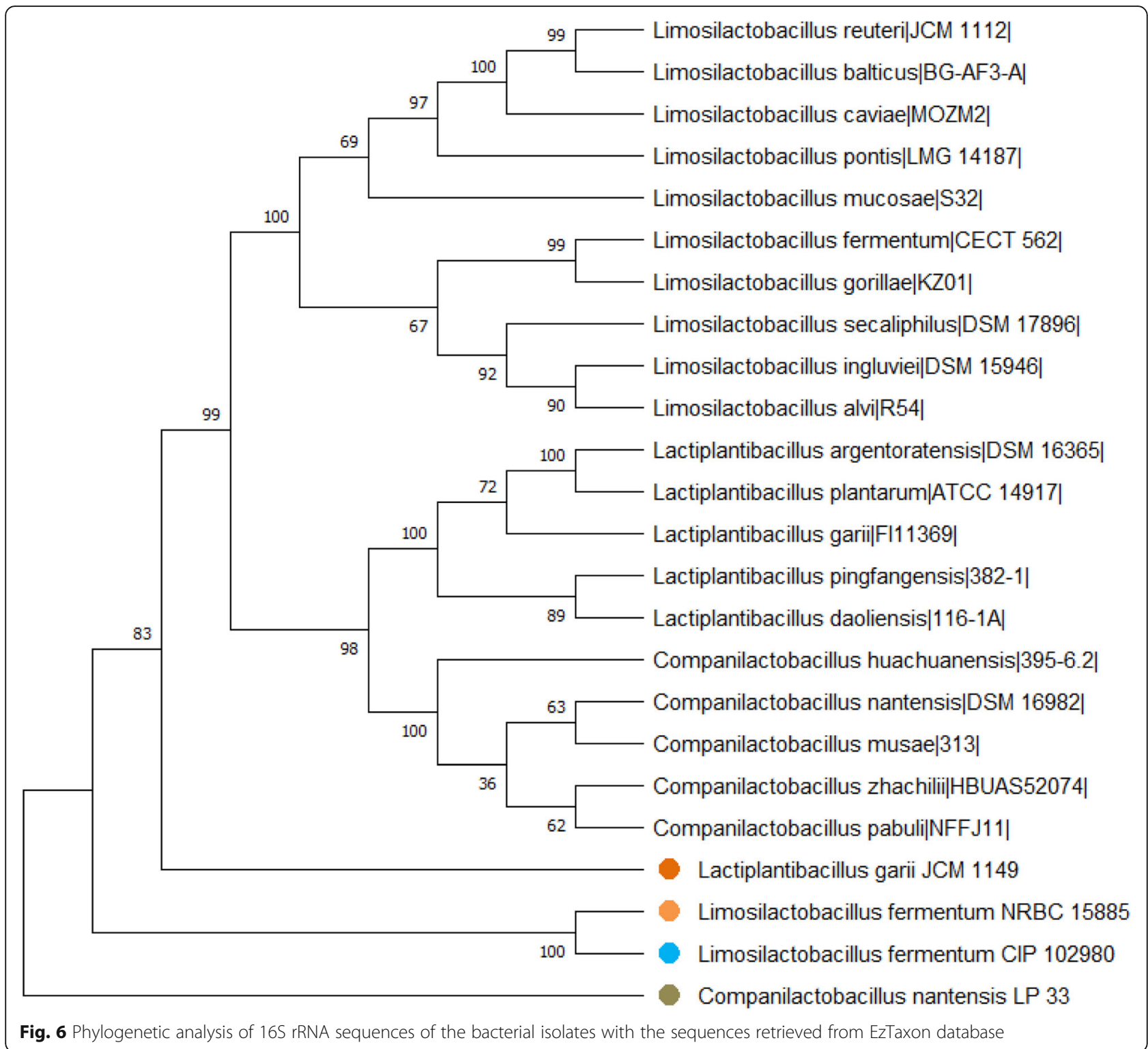

of these strains could inhibit the growth of B. cereus, Klebsiella pneumonia, S. typhimurium, S. aureus, and E. coli. The inhibitory activity demonstrated by crude bacteriocin against these organisms is a strong pointer to the presence of active bacteriocin in the test supernatant. Similar results have been observed in experiments related to the inhibitory effect of bacteriocin produced by other Lactobacillus species (Voidarou et al. 2020; Onipede et al. 2020). Jena et al. (2013) reported that bacteriocin PJ4, produced by Lactobacillus helveticus, was active against some Gram-positive and Gram-negative pathogens such as Enterococcus faecalis, S. aureus, $P$. aeruginosa, and E. coli. Furthermore, bacteriocin produced by Lactococcus lactis has been reported to inhibit the growth of methicillin-resistant Staphylococcus aureus (Simons et al. 2020). It was observed that fermented foods are rich in LAB that can produce bacteriocin with creditable inhibitory ability. This is in concordance with the findings of Upendra et al. (2016) on the production of bacteriocin (Nisin) from lactic acid bacteria isolated from selected fermented food sources, such as curd, mayonnaise, and jelly, in India. They obtained a crude extract of bacteriocin from the selected food samples which displayed antagonistic effect against $E$. coli and Kleibshella sp. using agar well diffusion assay.

Production of bacteriocin and optimal cell growth are complementary to each other (Oshoma et al. 2020). Similarly, Ashokkumar et al. (2011) reported that bacteriocin production is greatly influenced by the $\mathrm{pH}$, temperature, and nutrient levels of the culture environment. This study observed optimal 


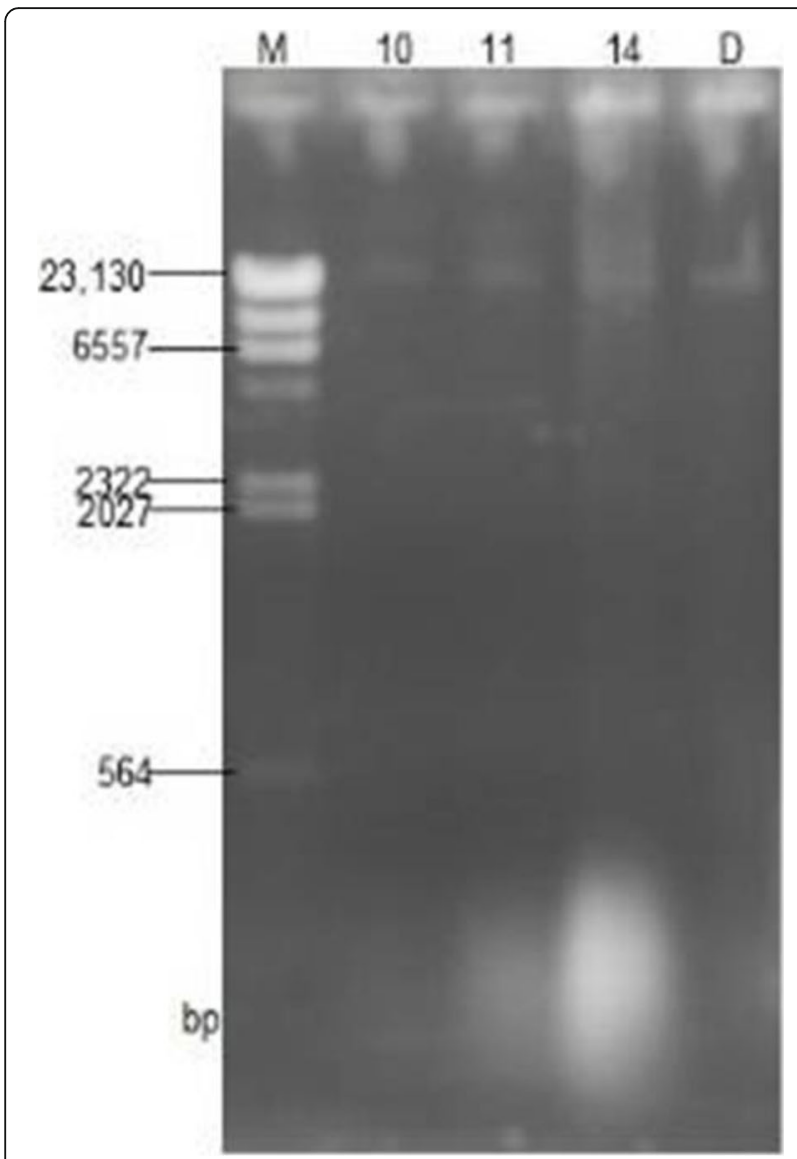

Fig. 7 Molecular weight bands of different purified bacteriocins on SDS PAGE gel

growth and bacteriocin production at $\mathrm{pH} 5.0$ and $2.5 \% \mathrm{NaCl}$ concentration when cultures were incubated at $40{ }^{\circ} \mathrm{C}$. This is similar to the findings of the studies conducted by Yang et al. (2018). However, Babalola (2007) observed optimum bacteriocin production by Lactococcus lactis at a $\mathrm{pH}$ value of 6 .

The biochemical and phylogenetic analyses of the characterized $L A B$ revealed that all the bacteriocinogenic LAB belong to the genera Lactobacillus. The LAB species identified in this study were common inhabitants of a variety of fermented food products. This finding was consistent with the results of other studies, which disclosed that Lactococcus spp. are predominant in fermented food samples (Sharma et al. 2020). In a similar study, Vantsawa et al. (2017) evaluated the lactic acid bacteria with probiotic potential from fermented cow milk (nono) in Unguwa Rimi, Kaduna State, Nigeria. They obtained 6 pure colonies which all turned out to be Lactobacillus strains on characterization using morphological, biochemical and carbohydrate fermentation tests.

Bacteriocins can be used as antimicrobial agents either as powdered food ingredients, purified, or partially purified-peptides or through bacteriocinogenic LAB cultures. The combined application of different LABbacteriocins may effectively reduce the possible development of resistant bacterial populations and improve the safety/quality and shelf-life of food products. However, further research is required to gain insights into the molecular mechanisms involved in bacteriocin production, immunity, and mode of action.

\section{Conclusion}

The results show that 9 LAB strains out of 194 isolates showed bacteriocin activity. The bacteriocins produced from 4 out of the 9 LAB were able to inhibit the growth of pathogenic strains of B. cereus, Klebsiella pneumonia, and $S$. typhimurium which were isolated from minced pie. The 4 isolates were identified as Limosilactobacillus fermentum NBRC15885, Limosilactobacillus fermentum CIP102980, Companilactobacillus nantensis LP33, and Lactiplantibacillus garii JCM1149. This research has demonstrated that bacteriocin-producing LAB with good primary probiotic properties can be isolated from fufu, nono, ogi, and kunu.

\section{Acknowledgements}

The authors would like to thank the staff of FIIRO for their technical support in this research work.

\section{Authors' contributions}

All authors contributed substantially towards the paper.

\section{Funding}

There was no form of financing for this research.

Availability of data and materials

All data generated or analyzed during this study are included in this published article.

\section{Declarations}

Ethics approval and consent to participate

Not applicable

\section{Consent for publication}

Not applicable

\section{Competing interests}

The authors declare that they have no competing interests.

\section{Author details}

'Department of Microbiology, Faculty of Life Sciences, University of Benin, Private Mail Bag, Benin City, Edo State 1154, Nigeria. ${ }^{2}$ Food Security and Safety Niche Area, Faculty of Natural and Agricultural Sciences, North-West University, Private Bag X2046, Mmabatho 2735, South Africa.

Received: 25 June 2021 Accepted: 20 September 2021

Published online: 13 November 2021

\section{References}

Akindolire MA, Babalola OO, Ateba CN (2015) Detection of antibiotic-resistant Staphylococcus aureus from milk: a public health implication. Int J Environ Res Public Health 12(9):10254-10275. https://doi.org/10.3390/ijerph120910254 Amarantini C, Satwika D, Budiarso TY, Yunita ER, Laheba EA (2019) Screening of antimicrobial-producing lactic acid bacteria isolated from traditional fish fermentation against pathogenic bacteria. J Physics 1397:5-25. https://doi. org/10.1088/1742-6596/1397/1/012045 
Ashokkumar S, Krishnaa SR, Pavithrab V, Hemalathab V, Ingalea P (2011) Production and antibacterial activity of bacteriocin by Lactobacillus paracasei isolated from donkey milk. Int J Curr Sci 1:109-115

Ayivi RD, Gyawali R, Krastanov A, Aljaloud SO, Worku M, Tahergorabi R, Silva RC, Ibrahim SA (2020) Lactic acid bacteria: food safety and human health applications. Diary 1(3):202-232. https://doi.org/10.3390/dairy1030015

Ayodeji BD, Piccirillo C, Ferraro V, Moreira PR, Obadina AO, Sanni LO, Pintado ME (2017) Screening and molecular identification of lactic acid bacteria from gar and fufu and gari effluenlts. Ann Microbiol 67(1):123-133. https://doi.org/10.1 007/s13213-016-1243-1

Babalola OO (2007) Characterization of two isolated lactococcal strains with respect to bacteriocin-concentrations. Afr J Food Sci 1(1):5-10

Balouiri M, Sadiki M, Ibnsouda SK (2016) Methods for in vitro evaluating antimicrobial activity: A review Journal of Pharmaceutical Analysis. J Pharm Anal 6:71-79

Bello OO, Babalola OO, Adegboye MF, Fashola M, Bello KT (2018) Partial purification, characterization and application of bacteriocin from bacteria isolated from Parkia biglobosa seeds. NESciences 3:72-94

Bello OO, Bankole SA, Babalola OO (2016) Bacteriocin detection from seeds of Colocynthis citrullus and evaluation of its antibacterial activities. IRUONAS 3:215-248

Benmouna Z, Dalache F, Karem N, Zadi-Karam H (2018) Optimization and some characteristics of bacteriocin produced by Enterococcus sp. CM9 collected from Mauritaninan Camel milk. Emir J Food Agric 30(4):275-282

Caniça M, Manageiro V, Abriouel H, Moran-Gilad J, Franz C (2019) Antibiotic resistance in foodborne bacteria. Trends Food Sci Technol 84:41-44. https:// doi.org/10.1016/j.tifs.2018.08.001

Carr FJ, Chill D, Maida N (2002) The lactic acid bacteria: a literature survey. Crit Rev Microbiol 28(4):281-370. https://doi.org/10.1080/1040-840291046759

Castro-Sanchez E, Moore LSP, Husson F, Holmes AH (2016) What are the factors driving antimicrobial resistance? Perspectives from a public event in London, England. BMC Infect Dis 16(1):465-470. https://doi.org/10.1186/s12879-016-1810-x

Coderoni S, Perito MA (2020) Sustainable consumption in the circular economy. An analysis of consumers' purchase intentions for waste-to-value food. J Clean Prod 252:119870. https://doi.org/10.1016/j.jclepro.2019.119870

Dada IO, Awotunde AO (2017) Consumption profile, consumer preference and serving occasions of indigenous non-alcoholic beverages from Nigerian foodstuffs. Int J Health Sci 7(12):168-175

Deraz SF, Karlsson EN, Hedström M, Andersson MM, Mattiasson B (2005) Purification and characterisation of acidocin D20079, a bacteriocin produced by Lactobacillus acidophilus DSM 20079. J Biotechnol 117(4):343-354. https:// doi.org/10.1016/j.jbiotec.2005.02.005

Egwim E, Musa A, Abubakar Y, Mainuna B (2013) Nigerian indigenous fermented foods: processes and prospects. In: Mycotoxin and Food Safety in Developing Countries. Makun HA, Ed., InTech, Croatia, pp 154-179

Georgiou NA, Garssen J, Witkamp RF (2011) Pharma-nutrition interface: the gap is narrowing. Eur J Pharmacol 651(1-3):1-8. https://doi.org/10.1016/j.ejphar.2010.11.007

Gomez-Gallego C, Garcia-Mantrana I, Salminen S, Collado MC (2016) The human milk microbiome and factors influencing its composition and activity. Semin Fetal Neonatal Med 21(6):400-405. https://doi.org/10.1016/ j.siny.2016.05.003

Hassan MU, Nayab H, Rehman TR, Williamson MP, Haq KU, Shafi N, Shafique F (2020) Characterisation of bacteriocin produced by Lactobacillus spp. isolated from the traditional Pakistani yoghurt and their antimicrobial activity against common foodborne pathogens. Biomed Res Int 2020:1-10. https://doi.org/1 $0.1155 / 2020 / 8281623$

Hockett KL, Baltrus DA (2017) Use of the soft-agar overlay technique to screen for bacterially produced inhibitory compounds. J Vis Exp 119:1-5

Imade EE, Ikenebomeh MJ, Obayagbona ON, Igiehon ON (2013) Evaluation of changes in the microbial profile, physico-chemical and nutritional attributes during the bioconversion of soursop (Annona muricata) must to wine. Niger J Biotechnol 25:1-11

Islam KN, Akbar T, Akther F, Islam NN, (2016) Characterization and confirmation of Lactobacillus spp. from selective regional youghurts for probiotic and interference with pathogenic bacterial growth. Asian J Biol Sci 9(1):1-9.

Jay JM (2000) Fermentation and fermented dairy products. In: Modern Food Microbiology, 6th edn. An Aspen Publication, Aspen Publishers, Inc, Gaithersburg, USA, pp 113-130

Jena PK, Trivedi D, Chaudhary H, Sahoo TK, Seshadri S (2013) Bacteriocin PJ4 active against enteric pathogen produced by Lactobacillus helveticus PJ4 isolated from gut microflora of wistar rat (Rattus norvegicus): partial purification and characterization of bacteriocin. Appl Biochem Biotechnol 169(7):2088-2100. https://doi.org/10.1007/s12010-012-0044-7
Karthikeyan V, Santosh SW (2009) Isolation and partial characterization of bacteriocin produced from Lactobacillus plantarum. Afr J Microbiol Res 3(5):233-239

Kim H, Kim JS (2014) A guide to genome engineering with programmable nucleases. Nat Rev Genet 15(5):321-334. https://doi.org/10.1038/nrg3686

Lowry O, Rosebrough N, Farr A, Randall R (1951) Protein measurement with the Folin phenol reagent. J Biol Chem 193(1):265-275. https://doi.org/10.1016/ S0021-9258(19)52451-6

Mariam SH, Zegeye N, Tariku T, Andargie E, Endalafer N, Aseffa A (2014) Potential of cell-free supernatants from cultures of selected lactic acid bacteria and yeast obtained from local fermented foods as inhibitors of Listeria monocytogenes, Salmonella spp. and Staphylococcus aureus. BMC Res Notes 7:606-615

Negash AW, Tsehai BA (2020) Current applications of bacteriocin. Int J Microbiol 2020:1-7. https://doi.org/10.1155/2020/4374891

Nwaiwu O, Aduba CC, Igbokwe VC, Sam CE, Ukwuru MU (2020) Traditional and Artisanal Beverages in Nigeria: Microbial Diversity and Safety Issues. Bev 6:53-75

Ogbeibu AE (2005) Biostatistics, a Practical Approach to Research and Data Handling. Mindex Publishing Company Ltd, Benin. 264pp.

Onipede GO, Aremu BR, Sanni Al, Babalola OO (2020) Molecular study of the phytase gene in lactic acid bacteria isolated from Ogi and Kunun-Zaki, African fermented cereal gruel and beverage. App Food Biotechnol 7:49-60

Oshoma CE, Allen OA, Oyedoh PO (2020) Growth enhancement of lactic acid bacteria for production of bacteriocin using a local condiment supplemented with nitrogen sources. Trop J Nat Prod Res 4(8):411-416

Parada JL, Caron CR, Bianchi A, Medeiros P, Soccol CR (2007) Bacteriocins from lactic acid bacteria: purification, properties and use as biopreservatives. Braz Arch Biol Technol 50(3):521-542

Perito MA, Chiodo E, Serio A, Paparella A, Fantini (2020) Factors influencing consumers' attitude towards biopreservatives. Sustain 12(24):10338-10350. https://doi.org/10.3390/su122410338

Prosekov AY, Babich OO, Bespomestnykh KV, (2013) Identification of industrially important lactic acid bacteria in foodstuffs. Foods Raw Mater. 1(2):42-45

Putria I, Jannaha SN, Purwantisaria S (2020) Isolation and characterization of lactic acid bacteria from Apis mellifera and their potential as antibacterial using in vitro test against growth of Listeria monocytogenes and Escherichia coli. NICHE J Trop Biol 3(1):26-34

Sharma R, Garg P, Kumar P, Bhatia SK, Kulshrestha S (2020) Microbial fermentation and its role in quality improvement of fermented foods. Fermentation 6(106):1-20

Simons A, Alhanout K, Duval RE (2020) Bacteriocins, antimicrobial peptides from bacterial origin: overview of their biology and their impact against multidrug-resistant bacteria. Microorganisms. 8(5):639-670. https://doi.org/1 0.3390/microorganisms8050639

Soltani S, Hammami R, Cotter PD, Rebuffat S, Said LB, Gaudreau H, B'edard F, Biron E, Drider D, Fliss I (2021) Bacteriocins as a new generation of antimicrobials: toxicity aspects and regulations. FEMS Microbiol Rev 45(1):124. https://doi.org/10.1093/femsre/fuaa039

Tatsinkou FB, Goghomu S, Tongwa M, Ndjouenkeu R, Cho-Ngwa (2017) Screening for bacteriocins producing probiotic bacteria from fermented sap of palm trees (Elaeis guineesis and Raffia sudanica): production and partial characterization of bacteriocins. J Appl Biotechnol \& Bioeng 2(1):1-8

Todorov SD, Dicks LMT (2004) Comparison of two methods for purification of plantaricin ST31, a bacteriocin produced by Lactobacillus plantarumST31. Enzyme Microb Technol 36:318-326

Upendra RS, Khandelwal P, Jana K, Kumar NA, Devi MG, Stephaney ML (2016) Bacteriocin production from indigenous strains of lactic acid bacteria isolated from selected fermented food sources. Int J Pharm Res Health Sci 4(1):982-990

Valgas C, De Souza SM, Smânia EFA (2007) Screening methods to determine antibacterial activity of natural products. Braz J Microbiol 38(2):369-380. https://doi.org/10.1590/S1517-83822007000200034

Vantsawa PA, Maryah UT, Timothy B (2017) Isolation and identification of lactic acid bacteria with probiotic potential from fermented cow milk (nono) in Unguwar Rimi, Kaduna State, Nigeria. Am J Mol Biol 7(02):99-106. https://doi. org/10.4236/ajmb.2017.72008

Vasilchenko AS, Vasilchenko AV, Valyshev AV, Rogozhin EA (2018) A novel highmolecular-mass bacteriocin produced by Enterococcus faecium: biochemical features and mode of action. Probiotics Antimicrob Proteins 10(3):427-434. https://doi.org/10.1007/s12602-018-9392-0

Voidarou C, Alexopoulos A, Tsinas A, Rozos G, Tzora A, Skoufos L, Varzakas T, Bezirtzoglou E (2020) Effectiveness of bacteriocin-producing lactic acid bacteria and bifidobacterium isolated from honeycombs against spoilage 
microorganisms and pathogens isolated from fruits and vegetables. Appl Sci 10(20):1-18. https://doi.org/10.3390/app10207309

Witkamp RF, Norren KV (2018) Let thy food be thy medicine when possible. Eur J Pharmacol 836:102-114. https://doi.org/10.1016/j.ejphar.2018.06.026

Yang E, Fan L, Yan J, Jiang Y, Doucette C, Fillmore S, Walker B (2018) Influence of culture media, $\mathrm{pH}$ and temperature on growth and bacteriocin production of bacteriocinogenic lactic acid bacteria. AMB Expr 8(1):10-24. https://doi. org/10.1186/s13568-018-0536-0

Yoon SH, Ha SM, Kwon S, Lim J, Kim Y, Seo H, Chun J (2017) Introducing EzBioCloud: a taxonomically united database of 165 rRNA gene sequences and whole-genome assemblies. Int J Syst Evol Microbiol 67(5):1281-1286. https://doi.org/10.1099/ijsem.0.001755

Yusuf MA (2013) Lactic acid bacteria: bacteriocin producer: a mini review. J Pharm 3(4):44-50

Zhang P, Timakov B, Stankiewicz RL, Turgut IY (2000) A trans-activator on the Drosophila $Y$ chromosome regulates gene expression in the male germ line. Genetica 109(2):141-150

Zheng J, Wittouck S, Salvetti E, Franz CM, HMB H, Mattarelli P, Toole PWO, Pot B, Vandamme P, Walter J, Watanabe K, Wuyts S, Felis GE, Gänzle MG, Lebeer S (2020) A taxonomic note on the genus Lactobacillus: description of 23 novel genera, emended description of the genus Lactobacillus Beijerinck 1901, and union of Lactobacillaceae and Leuconostocaceae Int. J Syst Evol Microbiol 70(4):2782-2858. https://doi.org/10.1099/ijsem.0.004107

\section{Publisher's Note}

Springer Nature remains neutral with regard to jurisdictional claims in published maps and institutional affiliations.

Ready to submit your research? Choose BMC and benefit from:

- fast, convenient online submission

- thorough peer review by experienced researchers in your field

- rapid publication on acceptance

- support for research data, including large and complex data types

- gold Open Access which fosters wider collaboration and increased citations

- maximum visibility for your research: over $100 \mathrm{M}$ website views per year

At $\mathrm{BMC}$, research is always in progress.

Learn more biomedcentral.com/submissions 